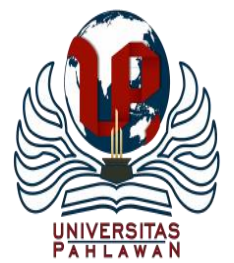

Edukatif : Jurnal Ilmu Pendidikan Volume 3 Nomor 2 Tahun 2021 Halm 549 - 561 EDUKATIF: JURNAL ILMU PENDIDIKAN

Research \& Learning in Education

https:/ledukatif.org/index.php/edukatif/index

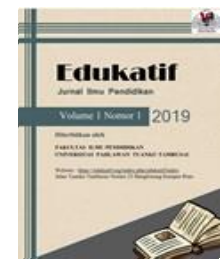

\title{
Peran Terekat Sufi Serta Relevansinya Terhadap Pendidikan Islam Modern
}

\author{
Herdian Kertayasa $^{1 凶}$, Alfyan Syach ${ }^{2}$, Rini Novianti Yusuf ${ }^{3}$, Asep Supriatna ${ }^{4}$
}

Prodi Pendidikan Guru Madrasah Ibtidaiyah, STIT Rakeyan Santang Karawang, Indonesia,

Prodi Pendidikan Islam Anak Usia Dini, STIT Rakeyan Santang Karawang, Indonesia ${ }^{4}$

E-mail : herdianhaz@gmail.com ${ }^{1}$, alfyansyach38@ gmail.com ${ }^{2}$, rininovi48@gmail.com ${ }^{3}$, aasepstea@gmail.com ${ }^{4}$

\begin{abstract}
Abstrak
Di era modern ini, seringkali dijumpai orang-orang masa sekarang (manusia modern) yang pandangan keagamaannya masih bersifat legal-formal. Dengan fenomena tersebut harus berusaha untuk mencoba mengembalikan semangat keberagamaan masyarakat modern dengan menawarkan pendekatan tasawuf yaitu dengan cara menerapkan sistem metode tarekat sufi terhadap mereka khususnya kepada para pelajar agar dapat terhindar dari efek negatif arus modernisasi. Penelitian ini bertujuan mendeskripsikan Peran Tarekat Sufi Serta Relevansinya Terhadap Pendidikan Islam Modern. Jenis penelitian yang digunakan peneliti adalah library research atau penelitian kepustakaan. Dalam pengambilan data diambil dari beberapa sumber diantaranya; al-Quran, Hadis, Buku-buku, Kitab-kitab klasik dan referensi-referensi yang menunjang penelitian ini seperti pendapat para Ulama dan para pakar pendidikan Islam. Hasil penelitian ini menunjukkan; 1) Tarekat Sufi relevan dari ajaran Islam menempati posisi sentral yaitu tauhid, syariat, dan akhlak, 2) Relevan sangat memperhatikan aspek keseimbangan dan keharmonisan kehidupan, 3) Relevan setiap pengamalnya agar membangun kehidupan yang lebih efektif, produktif, dan kontemplatif melalui pendekatan komunitas belajar mengajar (learning society), 4) Relevan dengan nilai etika etos kerja, serta nilai etika pengembangan peradaban, dengan segala dinamikanya. Implikasinya peran tarekat menjadi jawaban atas semua problematika kehidupan, harapan terbesar eksistensi tarekat sufi ini, menjadikan manusia berpaling sejenak untuk mangapai lagi sifat ke-Ilahiannya yang sering kali pudar dengan modernisme.
\end{abstract}

Kata Kunci: Tarekat Sufi, Pendidikan Islam, Masyarakat Modern, Tasawuf.

\begin{abstract}
In this modern era, we often find people today (modern humans) whose religious views are still formal-legal. With this phenomenon, we have to restore the religious spirit of modern society by offering a Sufism approach, namely by applying the Sufi order system method to them, especially to students so that they can avoid the negative effects of modernization. This study aims to describe the role of the Sufi order and its relevance to modern Islamic education. The type of research used by researchers is library research. In retrieving data from several sources including; al-Quran, Hadith, books, classical books and references that support this research such as the opinions of scholars and experts in Islamic education. The results of this study indicate; 1) The relevant Sufi order from Islamic teachings occupies a central position, namely monotheism, sharia, and morals, 2) Relevant pays close attention to aspects of life balance and harmony, 3) Relevant each of its practitioners in order to build a more effective, productive, and contemplative life through a learning community approach teaching (learning society), 4) Relevant to the ethical value of work ethic, as well as the ethical value of civilization development, with all its dynamics. The implication is that the role of the tarekat is the answer to all the problems of life, the greatest hope for the existence of this Sufi order, to make humans turn away for a moment to regain their divine nature which is often faded with modernism.
\end{abstract}

Keywords: Tarekat Sufi, Islamic Education, Modern Society, Sufism

Copyright (c) 2021 Herdian Kertayasa, Alfyan Syach, Rini Novianti Yusuf, Asep Supriatna $\triangle$ Corresponding author

Email: herdianhaz@gmail.com

DOI : https://doi.org/10.31004/edukatif.v3i2.358

ISSN 2656-8063 (Media Cetak) ISSN 2656-8071 (Media Online)

Edukatif : Jurnal Ilmu Pendidikan Vol 3 No 2 Tahun 2021 p-ISSN 2656-8063 e-ISSN 2656-8071 


\section{PENDAHULUAN}

Manusia merupakan makhluk Allah yang diberi berbagai potensi ilahiah dan insaniah. Semuanya harus digali, dibina dan dikembangkan agar membawa manfaat yang sebear-besarnya. Pendidikan merupakan formula terbaik dalam menjalankannya. Proses pendidikan diniatkan ikhlas sebagai wujud ibadah kepada Allah SWT. pendidikan sering diartikan sebagai upaya memanusiakan manusia. Artinya dengan pendidikan harkat dan martabat manusia sebagai ciptaan Allah dengan status makhluk terbaik (ahsani taqwim) tetap terjaga secara utuh dan tidak terjatuh kepada derajat yang paling rendah (asfala safilin). Melalui pendidikan pula hakikat keberadaan manusia sebagai hamba Allah ('abd Allah) dan khalifa di muka bumi (khalifah fi al$a r d l)$ terjaga dan berkembang segenap potensinya. Dengan semua potensinya, manusia mampu menjalankan tugas pokok sebagai 'abdullah dan khalifah tersebut. Tugas manusia sebagai 'abdullah ialah beribadah (mengabdi) kepada Allah dengan benar sesuai tuntunan-Nya dan sunnah Rasul-Nya. Sedangkan tugas manusia sebagai khalifah ialah memakmurkan bumi (isti'mar al-ardl) dalam berbagai bentuknya, seperti mengolah, menanam, merawat, memanfaatkan hasilnya, termasuk menjaganya dari kerusakan.

Setiap umat atau negara memiliki tujuan pendidikan yang didasarkan pada falsafah negaranya. Proses pendidikan yang tidak memiliki tujuan akan berjalan tanpa arah dan orientasi yang jelas. Tujuan akan memandu gerak langkah proses edukatif yang dijalankan oleh para pelakunya sebagai sesuatu yang penuh makna dan jelas arah yang ingin dicapainya. Karena pendidikan merupakan proses kemanusiaan, maka fokus tujuan pendidikan Islam bermuara pada terbentuknya anak didik atau out put pendidikan yang sejalan dengan nilai-nilai Islam yang terkandung dalam dua sumber ajarannya; yaitu al-Quran dan Sunnah. Walaupun alQuran sendiri tidak mengungkap secara rinci tentang hal itu, namun tidak sedikit ayat yang memberi isyarat yang menuntut terbentuknya pribadi manusia (muslim) dengan berbagai kualifikasinya (Burhanuddin \& Anwar, 2014).

Warisan intelektual Islam masih merupakan realitas yang hidup, akan membimbingnya dari pinggir lingkaran ke pusat eksistensi. Di pihak lain, masuknya peradaban modern merupakan anti-tesis dari prinsipprinsip Islam yang dipegangnya. Di masyarakat muslim, senter masih terlihat, batasan-batasan lingkaran masih diketahui bentuknyam dimensi transenden masih hadir, ibadah ritual dilaksanakan, hukum Tuhan merupakan aturan pokok, figur wali masih hidup. Muslim yang hidup dipojok-pojok dunia Islam, terasing dari pengaruh modernism, dunianya homogeni, ketegangan kehidupannya normal. Muslim ini di pusat dunia Islam tersentuh modernisme, diwarnai ketegangan yang muncul dari pertarungan dua sistem nilai yang berlawanan, Barat dan Islam.

Krisis peradaban modern bersumber pada penolakan terhadap hakikat ruh, Tuhan, kehidupan akhirat, hidupnya hanya mengandalkan roti semata. Eksesnya, kekuatan manusia mengalami eksternalisasi. Berikutnya, menaklukan dunia tanpa batas. Interkasi dengan alam melalui proses desakralisasi alam. Mendapat kepuasan dari alam tanpa rasa tanggung jawab apapun. Munculah berbagai krisis dunia modern. Krisis kehidupan spiritual, juga krisis kehidupan sosial. Idealnya penguasa bumi ini, keatas berperan sebagai 'Abdullah dan ke bawah berperan sebagai khalifatullah. Dengan demikian keseimbangan hidupnya dapat dijaga yaitu menempuh jalan tasawuf.

Proses modernisasi di Barat memberi dampak positif -negatif. Positifnya membawa kemudahankemudahan dalam penyelesaian berbagai pesoalan kehidupan sedangkan negatifnya menimbulkan krisis makna hidup. Menghadapi kenyataan ini para pemikir berusaha keras mencari jalan keluar dengan caranay sendiri-sendiri. Dinamika pemikiran Islam sudah mulai menampakan pergolakannya ditengah para intelektual muda yang saling berargumentasi dan berebut hujah dengan landasan mainstreim pemikirannya masingmasing, seolah menandai akan kebangkitan khazanah Islam yang telah mencapai masa keemasannya ratusan 
tahun silam. Setidaknya peta kebangkitan itu dapat diidentifikasi dari dua kutub pemikiran yang semakin mewarnai pola fikir kaum intelektual Islam saat ini yang cenderung saling berhadap-hadapan (konfrontatif).

Fenomena ini difahami sebagai letupan-letupan atas proses interaksi yang logis terhadap realitas zaman yang berkembang cepat dan kompleks yang terkadang bisa diposisikan sebagai stimulus (rangsangan) yang cukup memberikan spirit para penganyam tarekat Sufi untuk selalu mengkontemporerkan wawasannya, sehingga tetap relevan disepanjang zaman.

Di era modern ini, seringkali dijumpai orang-orang masa sekarang (manusia modern) yang pandangan keagamaannya masih bersifat legal-formal. Untuk merespon fenomena tersebut, harus berusaha untuk mencoba mengembalikan semangat keberagamaan masyarakat modern dengan menawarkan pendekatan tasawuf yaitu dengan cara menerapkan sistem metode tarekat sufi terhadap mereka khususnya kepada para pelajar agar mereka dapat terhindar dari efek negatif arus modernisasi. Fenomena yang terjadi pada masyarakat dan dunia modern, pendidikan atau pelatihan khas sufistik dirasa menjadi perlu, karena pada awal budaya dan peradaban manusia, pendidikan pada hakikatnya merupakan suatu proses transformasi pengetahuan dalam menyebarkan nilai-nilai luhur, pendidikan yang khas seperti ini dapat memberikan kontribusi yang luar biasa bagi peradaban manusia. Dalam hal ini metode tarekat Sufi sangat diperlukan bagi para pelajar demi kesuksesan dan keberhasilan para peserta didik di masa depannya. Karena pendidikan sufi lebih menekankan pada pendidikan spiritual (Spiritual Quotient).

Tarekat sebenarnya tidak bisa lepas dari Pendidikan Islam, karena tarekat adalah pendidikan akhlak yang baik, karena tarekat sebagai proses untuk menjernihkan hati agar tercapai akhlakul karimah, khususnya Sufi maka harus ada cara yang di tempuh untuk dapat mencapai penyucian tersebut, yaitu kalau dalam Tarekat disebut dengan cara mujahadah (bersungguh-sungguh) dan riyadhoh (terus menerus) untuk mengendalikan nafsu. Peran Tarekat Sufi menjadi jawaban atas semua problematika kehidupan, sehingga keberadaan Tarekat Sufi ini, menjadikan manusia berpaling sejenak untuk mangapai lagi sifat ke-Ilahiannya yang sering kali pudar dengan modernisme.

Penelitian ini relatif baru karena berdasarkan riset sebelumnya dikutip dari penelitian (Saliyo, 2017) membahas Mencari Makna Hidup Dengan Jalan Sufi di Era Modern. Sehingga tidak secara komprehensif membahasa tentang tarekat sufi khusus dalam pendidikan Islam modern. Berdasarkan uraian diatas, dapat diketahui pentingnya penelitian ini sehingga penulis tertarik melakukan penelitian dengan tujuan dapat mendeskripsikan Peran Tarekat Sufi Serta Relevansinya Terhadap Pendidikan Islam Modern.

\section{METODE PENELITIAN}

Desain penelitian ini menggunakan pendekatan kualitatif. Pendekatan kualitatif desainnya bersifat umum, dan berubah-ubah atau berkembang sesuai dengan situasi di lapangan. Sebagaimana yang dijelaskan oleh (Sugiyono, 2011) bahwa "metode ini disebut juga dengan metode interpretive karena data hasil penelitian lebih berkenaan dengan interpretasi terhadap data yang ditemukan di lapangan". Selanjutnya (Putra \& Lisnawati, 2012) menyebutkan "desain penelitian kualitatif biasanya bersifat global, tidak terperinci, tidak pasti dan sangat fleksibel”. Dengan demikian desain hanya digunakan sebagai asumsi untuk melakukan penelitian, oleh karena itu desain pada penelitian kualitatif bersifat fleksibel dan terbuka.

(Arikunto, 2010) menjelaskan, studi deskriptif yaitu "mengumpulkan data sebanyak-banyaknya mengenai faktor-faktor yang merupakan pendukung terhadap penelitian". Kemudian (Sukardi, 2011) menambahkan, dalam penelitian ini peneliti melakukan eksplorasi, menggambarkan, dengan tujuan untuk dapat menerangkan dan memprediksi terhadap suatu gejala yang berlaku atas dasar data yang diperoleh di 
lapangan. Kemudian (Lexy, 2017) menyebutkan, laporan dari deskriptif akan berupa kutipan-kutipan data untuk memberikan gambaran penyajian pada laporan tersebut.

Adapun jenis penelitian yang digunakan peneliti adalah library research atau penelitian kepustakaan. (Subagyo, 1997) menjelaskan yang dimaksud penelitian kepustakaan sebagai berikut: Penelitian yang menjadikan data-data kepustakaan sebagai teori untuk dikaji dan ditelaah dalam memperoleh hipotesa atau konsepsi untuk mendapatkan hasil yang objektif. Dengan jenis ini informasi dapat diambil secara lengkap untuk menentukan tindakan ilmiah dalam penelitian sebagai instrumen penelitian memenuhi standar penunjang penelitian.

Dengan demikian, dalam penyusunan penelitian ini penulis menentukan topik yang akan dibahas yang kemudian dilanjutkan dengan mencari data-data baik itu yang relevan ataupun mendukung terhadap topik yang dibahas. Setelah mendapatkan data, penulis melakukan interpretasi atau penafsiran terhadap sumber data untuk memperoleh fakta tentang kajian yang akan dibahas. Setelah terkumpul maka data disusun secara sistematis dan terstruktur. Dalam hal ini penulis mengambil dari beberapa sumber diantaranya: al-Quran, Hadis, Buku-buku, Kitab-kitab klasik dan referensi-referensi yang menunjang penelitian ini, kemudian diinterpretasikan dari pendapat cendekiawan muslim, dan para pakar pendidikan untuk diambil kesimpulan.

Jenis data dalam penelitian ini adalah berupa tekstual atau konsep-konsep. Karena dalam penelitian ini Sebagaimana telah disebutkan di atas termasuk kedalam jenis studi literatur. Dengan demikian aspek-aspek yang peneliti analisis melingkupi definisi, konsep, pandangan, pemikiran dan argumentasi yang terdapat dalam literatur yang relevan dan mendukung tentang peran tarekat sufi dan pendidikan Islam modern.

\section{HASIL DAN PEMBAHASAN PENELITIAN}

\section{Konsep Tarekat Sufi}

Tinjauan analisis terhadap tasawuf menunjukan bahwa para sufi dengan berbagai aliran yang dianutnya memiliki konsepsi tentang jalan (tarekat) menuju Allah. Jalan ini dimulai dengan latihan-latihan rohaniyah (riyadhoh), lalu secara bertahap menempuh berbagai fase yang dikenal dengan maqam (tingkatan) dan hal (keadaan) dan berakhir dengan mengenal (ma'rifat) kepada Allah. Tingkatan pengenalan (ma'rifat) menjadi jargon yang umum banyak dikejar oleh para sufi. Kerangka sikap dan perilaku sufi di wujudkan dengan amalan-amalan dan metode tertentu yang disebut dengan tarekat. Atau jalan untuk menemukan, atau jalan untuk menemukan pengenalan ( $m a$ 'rifat) yang berlaku dikalangan sufi sering disebut sebagai sebuah kerangka ‘irfani (Anwar, 2019).

Pada perjalanan menuju Allah merupakan metode pengenalan (ma'rifat) secara rasa (rohaniyah) yang benar terhadap Allah. Manusia tidak akan tahu banyak mengenai penciptanya apabila belum melakukan perjalanan menuju Allah walaupun ia adalah orang yang beriman secara aqliyah. Hal ini karena adanya perbedaan yang dalam antara iman secara aqliyah atau logis-teoritis (Al-Iman Al-Aqli An-Nazhari) dan iman secara rasa (Al-Iman As-Syu'uri Ad-Dzauqi).

Dikalangan kaum sufi, urutan maqam-maqam ini berbeda-beda. Sebagian mereka merumuskan maqammaqam dengan sederhana, seperti rangkaian maqam qona'ah berikut ini : a) tanpa qona'ah, tawakal tidak akan tercapai, b) Tanpa tawakal taslim tidak akan ada, c) Tanpa tobat, inabah tidak akan ada, d) Tanpa wara', zuhud tidak akan ada.

Disamping istilah maqam, tedapat pula istilah hal. Istilah hal yang dimaksud disini adalah keadaan atau kondisi psikologis ketika seorang sufi mencapai maqam tertentu. Menurut At-Thusi, keadaan hal tidak termasuk usaha latihan-latihan rohaniyah (jalan) diantara contoh hal (keadaan) adalah keterpusatan diri 
(muraqabah), kehampiran atau kedekatan (qarb), cinta (hubb), takut (khauf), harap (raja'), rindu (syauq), intim (uns), tentram (thuma'ninah), penyaksian (musyahadah), dan yaqin.

Para sufi sendiri secara teliti menegaskan perbedaan maqam dan hal. Maqam menurut mereka, ditandai oleh kemapanan. Sementara hal justru mudah hilang. Maqam dapat dicapai seseorang dengan kehendak dan upayanya. Sementara hal dapat diperoleh seseorang tanpa disengaja. Mengenai hal ini, menurut Al-Qusyairi, dalam kitabnya Ar-Risalah Al-Qusyairiyah mengatakan: "Hal adalah makna yang datang pada kalbu dengan cara disengaja. Hal diperoleh tanpa daya dan upaya, baik dengan menari, bersedih hati, bersenang-senang, rasa tercekam, rasa rindu, rasa gelisah, atau rasa harap. Jelasnya hal sama dengan bakat, sedangkan maqam diperolah dengan daya dan upaya. Hal akan dating dengan sendirinya, sementera maqam dapat tetap dengan berupaya. Orang yang meraih maqam dapat tetap dalam tingkatannya, sementara orang yang meraih hal justru akan mudah lepas darinya" (Anwar, 2019).

\section{Prinsip Tarekat Sufi}

Menurut (Al-Jailani, Abdul Qadir, 2012) menjelaskan ada tujuh prinsip dasar yang menjadi asas tarekat, yaitu: 1) Mujahadah, 2) Tawakal, menurut (Hamka, 2015), tidaklah keluar dari garis tawakal, jika kita berusaha menghindarkan diri dari kemelaratan, baik yang menyinggung diri, harta benda, atau keturunan. Baik kemelaratan yang yakin akan datang, atau ragu akan datang, atau boleh jadi tidak kunjung datang. 3) Berbudi pekerti, dalam sebuah hadis Rasulullah SAW. bersabda "Yang paling utama yaitu orang yang paling baik budi pekertinya”, 4) Bersyukur, 5) Sabar, 6) Ridha, 7) Shidiq (Jujur/Benar),

\section{Pendidikan Islam Era Modern}

Pada dasarnya prinsip-prinsip pendidikan modern sangatlah banyak, diantaranya : prinsip kesuksesan pendidikan dipengaruhi oleh faktor Emotional Intelligence (EI/EQ) dan Spiritual Intelligence (SI/SQ), prinsip kebebasan dalam berkembang, prinsip pendidikan berdasar pada kebutuhan masyarakat, prinsip minat dan perhatian dalam bekerja (belajar), prinsip cepat dan efektif, prinsip kesenangan dalam belajar, dan lain-lain.

Ada sejumlah faktor yang mempengaruhi warna dan jalannya suatu proses perkembangan peserta didik, yaitu: 1) Faktor Hereditas/Genitas (keturunan) adalah sesuatu yang bersifat "given" dari Tuhan., 2) Faktor lingkungan, dibagi dalam dua bagian, yaitu prenatal (sebelum kelahiran) dan pascanatal (setelah kelahiran). Prenatal adalah masa dimana perkembangan anak banyak ditentukan oleh keberadaan orang tua. Ibu yang sedang mengandung yang terbiasa mengkonsumsi makanan yang bergizi tinggi, misalnya akan berpengaruh kepada keberadaan janin yang ada didalam kandungannya, Setelah anak lahir didunia, kondisi lingkungan keluarga juga sangat menentukan terhadap perkembangan anak. Anak yang tumbuh dalam lingkungan yang harmonis berkecenderungan menjadi anak yang baik. 3) Faktor Takdir Tuhan (Ketentuan Allah SWT), menurut Salisu Shehu dalam prespektif Islam, bukan hanya faktor hereditas dan faktor lingkungan yang penting dalam mempengaruhi perkembangan manusia. Faktor ketentuan Allah SWT hal yang juga mempengaruhi proses perkembangan dan pertumbuhan (Kholidah, Nur \& Nasih, Munjin, 2009).

Menurut (Sutikno, 2006) ada empat pilar pendidikan sekarang dan masa depan yang dicanangkan oleh UNESCO, yaitu : 1) Learning to know (belajar untuk mengetahui), 2) Learning to do (belajar untuk melakukan sesuatu), 3) Learning to be (belajar untuk menjadi seseorang), 4) Learning to live together (belajar untuk menjalani kehidupan bersama). Dengan demikian, tuntutan pendidikan sekarang dan masa depan harus diarahkan pada peningkatan kualitas kemampuan intelektual spritual dan profesional, serta sikap, kepribadian dan moral manusia pada umumnya. 
Karenanya, pendidikan Islam disamping untuk membentuk kepribadian Islam, juga diarahkan untuk membekali pemahaman terhadap tsaqafah Islam serta penguasaan sains dan teknologi secara seimbang. Berikut adalah korelasi hakikat hidup manusia dengan arah pendidikan Islam.

Bagan 1. Hakikat Manusia dengan Pendidikan Agama Islam

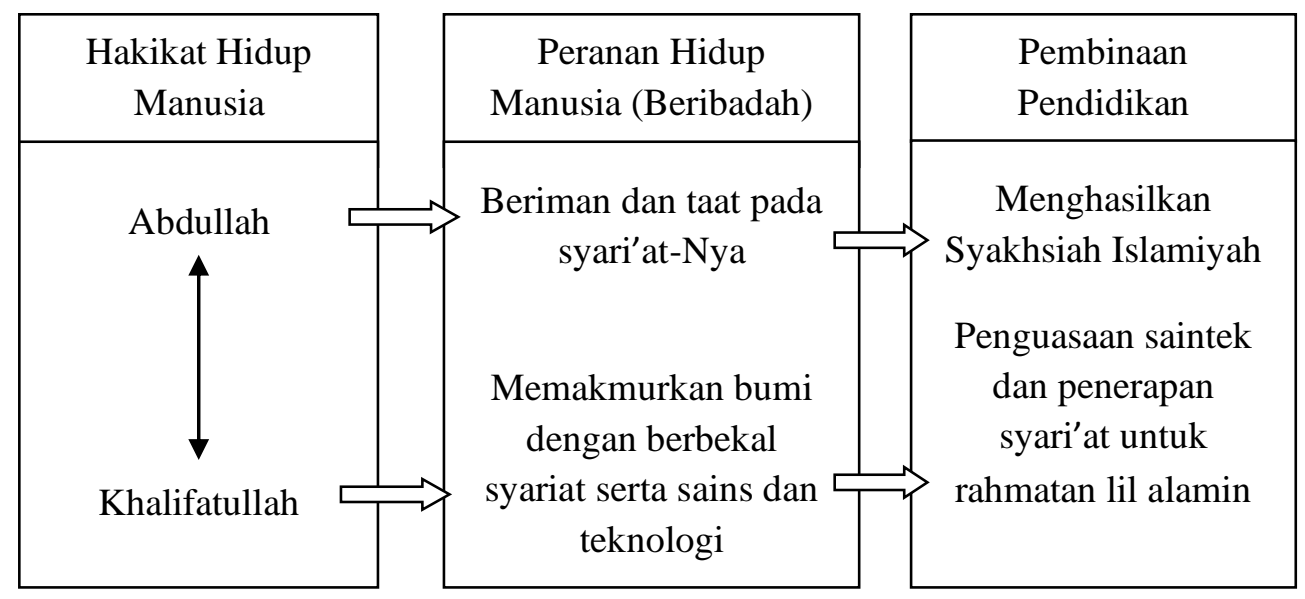

\section{Peran Tarekat Sufi dalam Pendidikan Islam di Zaman Modern}

1) Penyeimbang Kehidupan Duniawi dan Ukhrowi, Islam dibangun atas tiga pilar utama, yaitu akidah, syariat, dan akhlak. Ketiga pilar tersebut harus dijalankan secara bersama-sama dan seimbang, dengan tidak menonjolkan salah satunya. Melihat fenomena keragaman umat Islam khususnya di Indonesia masa sekarang ini terlihat ada ketidak seimbangan antara kepentingan duniawi dan ukhrowi. Tarekat menawarkan pembangunan diri manusia dan masyarakat secara utuh dan dinamis dengan senantiasa mengacu pada keterpaduan nilai-nilai intelektual, moral etika-estetika, kesadaran, keterbukaan, dan sikap bertanggung jawab (Salamah, 2005).

Kehadiran tasawuf bukanlah penghambat kehidupan duniawi akan tetapi menjadi penyeimbang antara kehidupan duniawi dan akhirat, seperti perkataan Ulama (As-Sakandari, Athoillah, Ibnu, 2011):

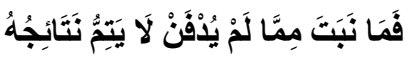

"Sesuatu yang tumbuh tanpa ditanam, dia tidak akan menghasilkan buah yang sempurna"

Sufisme perlu dimasyarakatkan pada kehidupan modern terutama dalam dunia pendidikan zaman sekarang, sekurangnya terdapat tiga tujuan yang dianggap penting yaitu: a) Menyelamatkan kemanusiaan dari kondisi kebingungan akibat hilangnya nilai-nilai spiritual, b) Memperkenalkan literatur atau pemahaman tentang aspek esoterik (kebatinan) Islam, baik terhadap masyarakat Islam yang mulai melupakannya maupun non islam, khususnya terhadap masyarakat barat, c) Aspek esoterik Islam, yakni sufisme, yaitu jantung dari ajaran Islam sehingga bila wilayah ini kering dan tidak berdenyut, maka keringlah aspek-aspek lain ajaran Islam. Intisari ajaran tasawuf bertujuan memperoleh hubungan langsung dan disadari dengan Tuhan, sehingga seseorang merasa dengan kesadaranya itu berada di kehadirat-Nya.

Selanjutnya ajaran akan mengatasi sikap stress yang dialami oleh manusia. Sikap materialistic dan hedonistic yang merajalela dalam kehidupan modern ini dapat diatasi dengan menerapkan konsep zuhud, yang pada intinya sikap yang tidak mau diperbudak atau terperangkap oleh pengaruh duniawi yang sementara itu. Jika sikap ini tidak mantap, maka ia tidak akan berani menggunakan segala cara untuk mencapai tujuan, sebab tujuan yang ingin dicapai dalam tasawuf adalah menuju Tuhan, maka caranyapun harus ditempuh dengan cara yang disukai Tuhan. Sebagai muslim yang beritikad saleh untuk agama, berkeyakinan baik dengan adanya 
perkembangan zaman, hendaknya menyeimbangi pekembangan tersebut bukan mengikuti bahkan terpengaruh perkembangan zaman.

2) Mengatasi Problematika Sekuleritas Kehidupan dan Ancaman Luar, dengan keberadaan tasawuf ini, menjadikan manusia berpaling sejenak untuk mangapai lagi sifat ke-Ilahiannya yang sering kali pudar dengan modernisme. Ajakan dan rayuan semata, telah membutakan sekilas perjuangan yang selama ini dirintis. Seyogyanya kemampuan mengeksistensikan kembali tasawuf-lah yang bisa menyayat sedikit gemerlap hujatan hitam di dunia modern ini. Dan solusinya yaitu agar dalam dunia pendidikan haruslah diterapkan amaliah ilmu tasawuf terhadap para pesrta didik.

Menurut (Mulyasa, 2006) diantara tujuh masalah pokok sistem pendidikan nasional yang pertama adalah menurunnya akhlak dan moral peserta didik, masalah yang lain adalah pemerataan kesempatan belajar, rendahnya efisiensi internal, status kelembagaan, manajemen, dan SDM yang belum professional.

Selama ini, tasawuf dipandang sebelah mata oleh sebagian umat Islam sendiri. Mereka beranggapan, seorang yang bertasawuf malah tidak kenal dengan dunia, tidak kenal toleransi, dan lainnya. Sebenarnya, jika diamati secara seksama justru dengan bertasawuf semakin banyak nilai, kesusilaan dan norma yang dilahirkan dari tubuh tasawuf. Hakikat tasawuf adalah mendekatkan diri kepada Allah melalui penyucian diri dan amaliyah-amaliyah Islam. Dan memang ada beberapa ayat yang memerintahkan untuk menyucikan diri (tazkiyyah al-nafs) di antaranya :

\section{قََْْن أَفْحَحَ مَنْ زَكَكَاهَا}

"Sungguh, bahagialah orang yang menyucikan jiwanya" (Q.S. Asy-syam : 9)

Jadi, peran tasawuf dalam kehidupan adalah menjadikan manusia berkeperibadian yang saleh dan berperilaku baik dan mulia serta ibadahnya berkualitas. Mereka yang masuk dalam sebuah tarekat atau aliran tasawuf dalam mengisi kesehariannya diharuskan untuk hidup sederhana, jujur, istiqamah dan tawadhu sebagai mana yang telah tersusun dalam maqomat dan ahwal Tarekat Sufi. Sebagaimana telah diungkapkan Imam Al-Junaidi bahwa seorang sufi diharuskan untuk melaksanakan maqomat (tahapan-tahapan) sufi yaitu diantaranya : taubat, al-wara', zuhud, fakir, sabar, ridha, dan tawakal (Muhammad Fauqi Hajjaj, 2010). Perilaku hidup Rasulullah SAW yang ada dalam sejarah kehidupannya merupakan bentuk praktis dari cara hidup seorang sufi.

Tarekat merupakan petualangan batin yang penuh keasyikan dan sarat dengan pesan-pesan spiritual yang dapat menentramkan batin manusia. Sebagai suatu sistem penghayatan keagamaan yang bersifat esoteric (Rusli, 2013). Ditengah-tengah situasi masyarakat yang cenderung mengarah kepada dekadensi moral, yang imbasnya mulai terasa dalam kehidupan secara langsung. Perubahan dan pembaharuan tersebut menjadi tanpa arah dan tidak teratur, bahkan menimbulkan kerusakan dan trauma sosial (Salamah, 2005). Tarekat tasawuf ini menjadi perhatian khusus dan dituntut perannya secara efektif dalam mengatasi masalah tersebut dengan memberikan makna, arah, dan kontrol terhadap setiap keterbukaan, kebebasan, dan demokrasi tidak akan kehilangan nilai, moral, dan etika.

Jadi, tujuan terpenting dari tasawuf adalah lahirnya akhlak yang baik dan menjadi orang yang bermanfaat bagi orang lain. Dalam kehidupan modern, tasawuf menjadi obat yang mengatasi krisis kerohanian manusia modern yang telah lepas dari pusat dirinya, sehingga ia tidak mengenal lagi siapa dirinya, arti dan tujuan dari hidupnya. 


\section{Relevansi Metode Tarekat Dengan Pendidikan Islam Modern}

Menurut (Kholidah, Nur \& Nasih, Munjin, 2009) relevansi pendidikan agama terdapat empat segi, yaitu relevansi dengan agama Islam, relevansi dengan perkembangan kehidupan, relevansi dengan lingkungan hidup anak didik, dan relevansi dengan tutntutan dunia pekerjaan. Dengan demikian relevansi metode Tarekat Sufi (ajaran tasawuf) memiliki relevansi (kesesuaian) terhadap empat segi tersebut yaitu :

(1) Relevansi Dengan Agama Islam Ajaran Islam yang dibawa oleh Nabi Muhammad SAW dari Allah SWT berisi pedoman hidup pokok yang mengatur hubungan manusia dengan Tuhannya, dengan dirinya sendiri, dengan manusia sesamanya, dengan makhluk bernyawa yang lain, dengan benda mati, dan dengan alam semesta. Ajaran Islam berwujud prinsip-prinsip atau pokok-pokok yang disesuaikan menurut lokasi atau keadaan umatnya. Pada masa Nabi Muhammad SAW prisip-prinsip atau pokok-pokok itu disesuaikan dengan kebutuhan umat manusia secara keseluruhan, yang dapat berlaku pada segala masa dan tempat. Menurut Abu Qasim An-Nashr Badzy sebagaimana yang dikutip oleh (Djamaluddin Ahmad Al-Buny, 2001) dalam kaitannya dengan akhlak sufi ia mengatakan :"Adapun asal usul tasawuf adalah melazimkan mentelaah AlQuran dan as-Sunah dengan meninggalkan semua perbuatan bid'ah. Al-Quran adalah jalan yang lurus menuju Allah. Sunnah Nabi Muhammad SAW juga jelasrealisasi dari isi Al-Quran yang tercantum dalam bentuk syari'at. Para sahabat Nabi SAW adalah contoh dari pelaku-pelaku sunnah utama”. Maka praktek hidup para sufi yang sahih adalah mengikuti Al-Quran sebagai pedoman ittiba' kepada sunnah Nabi SAW dengan penuh keikhlasan. Mengikuti dan menuruti pedoman dan pegangan hidup Islami dari dua pedoman yang ditinggalkan oleh baginda Rasulullah SAW, menjadi akhlak yang sangat diutamakan oleh para sufi. Barang siapa berpegang teguh kepada Al-Quran dan as-Sunah, maka ia telah behijrah dengan hati sanubari yang lurus menuju ma'rifatullah. Itulah ajaran sufi dan jalan yang mereka tempuh. Adanya anggapan salah terhadap ajaran tasawuf yang selama ini muncul seharusnya dihilangkan. Karena, memang tasawuf yang positif dapat membantu manusia dalam usaha mencapai hidup hakiki untuk mendekati kebenaran mutlak.

Menurut M.T. Ja'fari yang dikutif (Ni'am, 2008), memahami tasawuf positif sebagai tasawuf sejati yang bertujuan membangun manusia dari mimpi kehidupan dunia, dan mengingatkan bahwa tujuan inti penciptaan dunia wujud adalah agar manusia bergerak kearah kebaikan dan penyempurnaan. Tasawuf positif tidak sama sekali mengabaikan dunia wujud, baik yang berkaitan dengan manusia atau mahluk lain, tetapi bermaksud menjernihkan seluruh dunia dengan unsur Ilahiyah, dan memancarkan cahaya Ilahiyah kepada setiap lekuk dan liku dunia. Jika ternyata ada tasawuf yang dianggap negatif atau menyimpang dari syariat, maka tidaklah bijaksana untuk menolaknya secara keseluruhan. Tasawuf adalah aspek ajaran Islam yang lebih menekankan pada pentingnya penghayatan religiositas.

(2) Relevansi Dengan Perkembangan Kehidupan. Relevansi Tasawuf dengan problem dan perkembangan manusia modern adalah karena Tasawuf secara seimbang memberikan kesejukan batin dan disiplin syari'ah sekaligus. Ia bisa difahami sebagai pembentuk tingkah laku melalui pendekatan Tasawuf suluky, dan bisa memuaskan dahaga intelektual melalui pendekatan Tasawuf falsafy. Ia bisa diamalkan oleh setiap muslim, dari lapisan sosial manapun dan di tempat manapun. Secara fisik mereka menghadap satu arah, yatiu Ka'bah, dan secara rohaniah mereka berlomba lomba menempuh jalan (tarekat) melewati ahwal dan maqam menuju Allah SWT. Fenomena atau permasalahan yang timbulkan berbagai kerisis kehidupan, baik agama, pandangan hidup (waltanschuung), ideologi, kepemimpinan, politik, ekonomi, sosial budaya, dan kemanusiaan umumnya menunjukan bahwa sumbernya berasal dari krisis atau sakitnya spiritual. Ini pada dasarnya, bersumber dari rapuhnya pemahaman terhadap makna dan fungsi kehadiran Allah didalam hati, atau nurani manusia. Dalam kondisi demikian Tarekat sufi menawarkan kepada setiap manusia agar segera kembali (bertobat) kepada titik pusat eksistensi hakikat manusia, yaitu Allah dalam nuansa dan rona nafs almutmainnah (derajat nafsu yang tenang). 
Menurut (Ni'am, 2008), jika dikaitkan dengan kehidupan sekarang, kebutuhan terhadap tasawuf menjadi hal yang urgen buat umat Islam untuk membangun kerangka kehidupan yang lebih seimbang antara dunia dan akhirat. Melalui tasawuf pula, pembangunan mental-spiritual akan menjadi kontrol terhadap pesatnya pembangunan dibidang fisik-material. Modernisasi, disamping menjadi frame, yang dapat memberikan harapan baru bagi masa depan sejarah manusia, juga telah mereduksi kelengkapan kehidupan manusia sebagai elemen utuh yang terdiri dari dimensi material dan spiritual. Kecenderungan dominasi dimensi material pada masa ini telah menciptakan pencarian terhadap dimensi spirirtual manusia. Salah satu cara dalam pencarian dimensi spiritual (kerohanian) dalam Islam tersebut dapat ditemukan melalui tasawuf.

Kehidupan manusia saat ini seringkali dihinggapi rasa cemas, tidak percaya diri, dan krisis moral akibat mewahnya gaya hidup materialistik yang didapat. Maka pelarian dan pencarian akan kehidupan lain sebagai mana yang terdapat dalam tasawuf atau mistik adalah hal yang mungkin saja terjadi. Sebab disinilah mereka akan dapat melepaskan kejenuhan, atau mengisi kekosongan jiwa setelah dunia modern mereka gapai dengan mudah. Gejala kebangkitan spiritualitas pada era modern tersebut dalam buku megatrend tahun 2000 yang dikutip (Ni'am, 2008) adalah karena ilmu pengetahuan dan teknologi tidak dapat memberikan makna tentang kehidupan. Oleh karena itu, Naisbit dan Aburdene membuat jargon "spirituality yes, organized religion no". Ia mengatakan bahwa kemajuan yang dibarengi dengan kemakmuran pada masyarakat industri ternyata menimbulkan kemiskinan baru, yaitu kemiskinan batin. Mengeringnya rohani tersebut, seperti munculnya masalah dadakan yang bisa menimbulkan hal-hal kontroversial dikalangan mereka, memicu mereka untuk segera mengadakan koreksi, bahwa didalam dirinya ada sesuatu berharga yang hilang.

Dengan demikian, munculnya tasawuf beserta metode-metodenya, kebahagian dan ketenangan hidup dalam konteks dunia kemodernan secara umum dapat ditemukan atau paling tidak dapat dicari, dan hal itu tidak termasuk suatu yang berlebihan. Lebih khususnya untuk para pelajar generasi penerus penyambung peradaban demi kelangsungan kehidupan yang lebih baik. Islam pada hakikatnya sangat memperhatikan aspek keseimbangan dan keharmonisan, meliputi aspek lahir (eksoterik) dan batin (esoterik). Oleh karena itu tasawuf menempati posisi sentral diantara tiga aspek dasar Islam : tauhid, syariat, dan akhlak. Jika hakikat misi Islam adalah penyempurnaan akhlak dan moral, seperti dilukiskan dalam sebuah hadits Nabi Muhammad SAW, maka pelestarian tasawuf, baik dalam taraf teoritis maupun praktis, merupakan pelestarian nilai-nilai itu sendiri.

Di tengah-tengah situasi umat sekarang ini khususnya para kaum pelajar yang cenderung yang mengarah pada kebobrokan moral, hilangnya rasa percaya diri, serta mengeringnya rasa persatuan dan persaudaraan, kasih sayang, sopan santun, saling tolong menolong, dan semacamnya tasawuf memulai jadi sorotan serius. Peran serta tasawuf dituntut untuk bisa terlibat secara aktif dalam rangka mengatasi masalahmasalah yang dihadapi umat sebagai akibat dari modernisasi. Sementara anggapan bahwa sufisme identik dengan pola hidup asketis dan kepasrahan hidup total yang statis, yang selalu menjauhkan diri dari kehidupan sosial, tidak mau tahu tentang kehidupan sekitar dan sebagainya, anggapan seperti ini tidaklah selamanya benar, paling tidak hal itu bisa disaksikan dari tokoh-tokoh sufi yang sangat kreatif, dinamis, humanis, dan inklusif, misalnya Al-Ghazali, Al-Qusyairi, Al-Junaidi Al-Bagdadi, Jalaluddin Rumi, Ibnu 'Arabi, juga K.H. Achmad Siddiq, dan sebagainya. Oleh karenanya, tasawuf hendaknya dipandang sebagai kelanjutan yang wajar dari kebutuhan terhadap varian ilmu pengetahuan dalam Islam, layaknya fikih, teologi, dan filsafat.

Melalui tasawuf pula, pembangunan mental-spiritual akan menjadi kontrol terhadap pesatnya pembangunan di bidang fisik-material (Ni'am, 2008). Tasawuf adalah aspek ajaran Islam yang lebih menekankan pada pentingnya penghayatan religiositas. Karenanya, melalui kajian ini, tasawuf berguna sebagai solusi alternatif dalam menghadapi krisis spiritual dan problema besar bangsa dalam kehidupan modern khususnya dalam dunia pendidikan masa sekarang ini. 
(3) Relevansi dengan Lingkungan Hidup Anak Didik, menurut (Agustian, Ginanjar, 2012) bahwa kecerdasan spiritual sebagai kecerdasan untuk menghadapi persoalan makna atau value, yaitu kecerdasan untuk menempatkan prilaku dan hidup kita dalam konteks yang lebih luas dan kaya, kecerdasan untuk menilai bahwa tindakan atau jalan hidup seseorang lebih bermakna dibandingkan dengan yang lain. SQ adalah landasan yang diperlukan untuk memfungsikan IQ dan EQ secara efektif. Bahkan SQ merupakan kecerdasan tertinggi bagi kita. Menurut Salisu Shehu, yang dikutip oleh (Kholidah, Nur \& Nasih, Munjin, 2009) dalam prespektif Islam, bukan hanya faktor hereditas dan faktor lingkungan yang penting dalam mempengaruhi perkembangan manusia. Faktor ketentuan Allah SWT merupakan hal yang juga mempengaruhi proses perkembangan dan pertumbuhan. Dalam hal yang senada, (As-Sakandari, Athoillah, Ibnu, 2011) mengatakan:

$$
\text { سوابق الهمم لا تخرق اسوار الاقدار }
$$

"Kerasnya suatu usaha perjuangan, tidak akan mampu menembus tirai takdir".

Dalam hal ini metode tarekat Sufi sangat diperlukan bagi para pelajar demi kesuksesan dan keberhasilan para peserta didik di masa depannya. Karena pendidikan sufi lebih menekankan pada pendidikan spiritual (Spiritual Quotient). Menurut (Salamah, 2005) Tarekat Sufi mengajarkan kepada setiap pengamalnya agar membangun kehidupan yang lebih efektif, produktif, dan kontemplatif dalam rangka mengembangkan penyadaran kritis dan kreatif melalui pendekatan komunitas belajar mengajar (learning society) dalam suasana percepatan dinamika waktu dan perkembangan ilmu (sains) dan teknologi. Kearifan dalam sikap dan memilih prioritas apa yang dipelajari dan informasi apa yang disikapi sungguh-sungguh dalam proses percepatan ini merupakan ciri utama dari cara dan proses belajar-mengajar dalam kehidupan komunitas Tarekat sufi.

Salah satu ciri Muslim yang sempurna ialah cerdas serta pandai. Akal yang cerdas adalah karunia tuhan. Indikatornya ialah kecerdasan umum (IQ). Seperti yang telah disinggung sebelumnya, bahwa rohani ialah aspek manusia selain jasmani dan akal (logika). Menurut (Tafsir, 2010) rohani itu samar, ruwet, belum jelas batasannya, manusia belum tahu (atau tidak akan) memiliki cukup pengetahuan untuk mengetahui hakikatnya. Kebanyakan dalam istilah tasawwuf disebut qalb (kalbu) saja. Demikian juga dalam surat al- Hajj: 32 yang berbunyi :

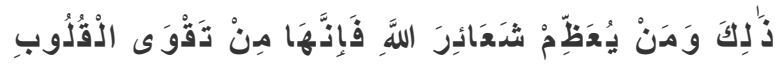

"Demikianlah (perintah Allah) dan barangsiapa mengagungkan syi'ar-syi'ar Allah, maka sesungguhnya itu timbul dari ketakwaan hati.” (Q.S. al- Hajj : 32)

Jelaslah bahwa kalbu sangat berkualitas tinggi. Qalb berpotensi untuk berdialog dengan Tuhan. Inilah yang dimaksud Al-Ghazali dengan ungkapan bahwa diluar akal dan jiwa, terdapat alat yang dapat menyikap pengetahuan yang gaib dan hal-hal yang akan terjadi di masa yang akan datang. Penyikapan pengetahuan seperti ini merupakan wacana irfaniyah. Hanya dengan saran qalb itulah, ilmu ma'rifat dapat diperoleh manusia (Tafsir, 2010).

(4) Relevansi dengan Tuntutan Dunia Pekerjaan. Pengalaman belajar agama hedaknya dapat memecahkan beraneka problem kehidupan keagamaan yang dialami siswa setelah menamatkan sekolah/madrasah dengan menerjuni berbagai ragam lapangan pekerjaan, khususnya yang menggelisahkan ketenangan menjalankan ibadahnya. Menurut (Salamah, 2005) ajaran Tarekat Sufi menyikapi bahwa profesionalisme dan keahlian dari seseorang manusia adalah sebagai salah satu keunggulan kemanusiaan yang harus senantiasa bersatu dasar, nilai dengan etika kemanusiaan, nilai denganetika ilmu, nilai denga etika keahlian, nilai denga etika etos kerja, serta nilai denga etika pengembangan peradaban, dengan segala dinamikanya. Karena itu, Allah memberi penghargaan setinggi-tingginya kepada setiap keahlian profesionalisme yang selalu dikaitkan dengan dimensi spritual Ilahiyah dalam kerangka ibadah. 
Tuntutan dunia pekerjaan bukan hanya mengandalkan keahlian dan keterampilan tetapi harus ada unsur kepekaan rohani dalam artian memiliki jiwa rohani yang mendalam, agar dalam pelaksaannya memiliki sifat jujur, sabar, semangat, dan rela berkorban. Dalam hal ini, metode tarekat Sufi sangat diperlukan bagi para pelajar demi kesuksesan dan keberhasilan para peserta didik di masa depannya baik dalam dunia pekerjaan ataupun dalam bersosialisasi dengan linkungannya.

Danah Zohar dan Ian Marshall mendefinisikan kecerdasan spiritual sebagai kecerdasan untuk menghadapi persoalan makna atau value, yaitu kecerdasan untuk menempatkan prilaku dan hidup kita dalam konteks yang lebih luas dan kaya, kecerdasan untuk menilai bahwa tindakan atau jalan hidup seseorang lebih bermakna dibandingkan dengan yang lain. SQ adalah landasan yang diperlukan untuk memfungsikan IQ dan EQ secara efektif. Bahkan SQ merupakan kecerdasan teritinggi bagi kita (Agustian, Ginanjar, 2012).

Sejalan dengan itu munculnya kemajuan dibidang ilmu pengetahuan dan teknologi (IPTEK) modern disamping mewarnakan berbagai kemudahan dan kenyamanan hidup, juga membuka peluang untuk melakukan kejahatan lebih canggih lagi, jika ilmu pengetahuan dan teknologi itu disalah gunakan. Semua orang mengharapkan agar IPTEK bermanfaat bagi manusia, dan caranya antara lain melalui pengembangan IPTEK yang berwawasan moral. Tentunya apabila amalan tarekat sufi dipraktekan dalam dunia pekerjaan sebagaimana yang terangkum dalam maqomat dan ahwal, maka kita akan menemukan ketenangan dan perasaan jiwa yang mendorong untuk hidup lebih optimis dan bertanggung jawab.

Berikut ini adalah bagan mengenai kerelevansian pendidikan tarekat sufi dengan pendidikan Islam di zaman sekarang.

Bagan 2. Relevansi Tarekat Sufi Terhadap Pendidikan Islam Modern

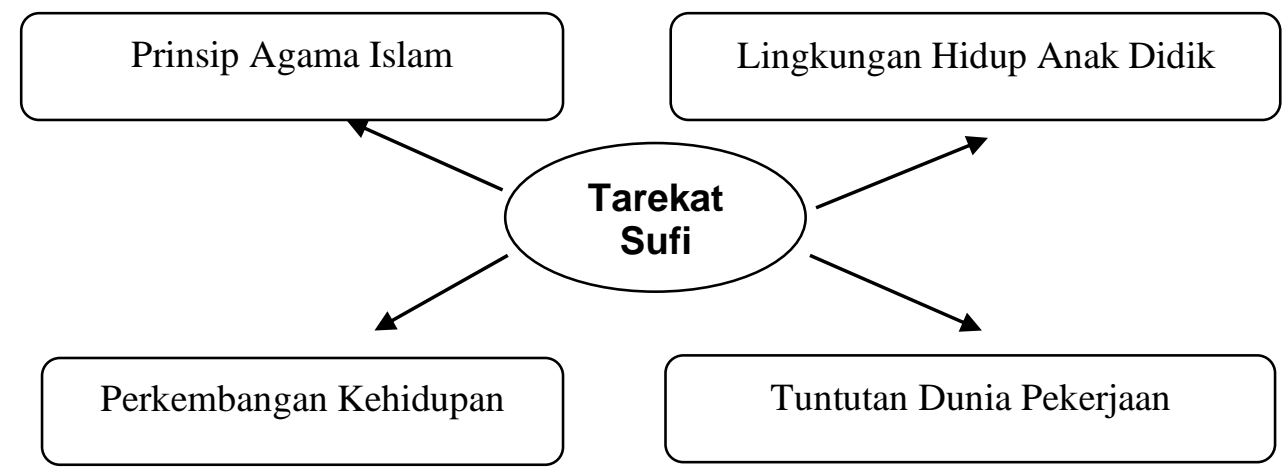

Demikian nampak jelaslah bahwa metode Tarekat Sufi sangatlah cocok dan relevan sekali untuk diperaktekan dalam dunia pendidikan agar para peserta didik mendapatkan cahaya ilmu, karena kebersihan hati yang menerimanya. Sebab ilmu adalah cahaya, sedangkan cahaya hanya bisa diterima oleh hati yang bersih. Peran tarekat sufi terhadap pendidikan Islam modern, disadarkan bahwa sumber segala yang ada ini berasal dari Tuhan. Dengan adanya bantuan tasawuf ini, maka ilmu pengetahuan satu dan lainya tidak akan bertabrakan karena ia berada dalam satu jalan dan satu tujuan. Peran tarekat sufi melatih manusia agar memiliki ketajaman batin dan kehalusan budi pekerti. Sikap batin dan kehalusan budi yang tajam ini menyebabkan ia akan selalu mengutamakan pertimbangan kemanusiaan pada setiap masalah yang dihadapi. Dengan demikian ia akan terhindar dari melakukan perbuatan-perbuatan yang tercela menurut agama, sehingga dapat berperan aktif dalam seluruh lapangan kehidupan, cerdas, aktif, kreatif, terampil, jujur, berdisiplin dan bermoral tinggi, demokratis dan toleran dengan mengutamakan persatuan bangsa. 
DOI: https://doi.org/10.31004/edukatif.v3i2.358

\section{KESIMPULAN}

Peran tarekat sufi menawarkan pembangunan diri manusia dan masyarakat secara utuh dan dinamis dengan senantiasa mengacu pada keterpaduan nilai-nilai intelektual, moral etika-estetika, kesadaran, keterbukaan, dan sikap bertanggung jawab. Keutuhan dan keterpaduan nilai-nilai tersebut tertuang dalam transformasi, identifikasi dan interasi sosial. Transformasi sosial tersebut tidak bisa dilepaskan dari upaya personal-sosial yang mengacu pada pembumian nilai, moral, dan etika agama dalam pembangunan karakter manusia dan masyarakat untuk memunculkan sifat-sifat adiluhung Ilahiyah. Peran tarekat yaitu menjadi jawaban atas semua problematika kehidupan, harapan terbesar dengan keberadaan tarekat sufi ini, menjadikan manusia berpaling sejenak untuk mangapai lagi sifat ke-Ilahiannya yang sering kali pudar dengan modernisme.

Berdasarkan analisis penulis bahwa kerelevansian Tarekat Sufi dengan pendidikan Islam modern dapat diperinci sebagai berikut : 1) Tarekat Sufi relevan dengan agama Islam, karena metode tarekat sufi merupakan bagian dari ajaran Islam dan tasawuf menempati posisi sentral diantara tiga aspek dasar Islam : tauhid, syariat, dan akhlak, 2) Tarekat Sufi relevan dengan perkembangan kehidupan, karena tarekat sufi pada hakikatnya sangat memperhatikan aspek keseimbangan dan keharmonisan kehidupan, yang meliputi aspek lahir (eksoterik) dan batin (esoterik), yang mana hal tersebut sumber dari kebahagiaan. Dan melemahnya nilai spiritualitas kehidupan, pada dasarnya bersumber dari rapuhnya pemahaman terhadap makna dan fungsi kehadiran Allah di dalam hati, atau nurani manusia, 3) Tarekat Sufi relevan dengan lingkungan hidup anak didik karena metode tarekat sufi mengajarkan kepada setiap pengamalnya agar membangun kehidupan yang lebih efektif, produktif, dan kontemplatif dalam rangka mengembangkan penyadaran kritis dan kreatif melalui pendekatan komunitas belajar mengajar (learning society) dalam suasana percepatan dinamika waktu dan perkembangan ilmu (sains) dan teknologi, 4) Tarekat Sufi relevan dengan tuntutan dunia pekerjaan karena metode tarekat sufi menyikapi bahwa profesionalisme dan keahlian dari seseorang manusia adalah sebagai salah satu keunggulan kemanusiaan yang harus senantiasa bersatu antara dasar, nilai dengan etika kemanusiaan, nilai dengan etika ilmu, nilai dengan etika keahlian, nilai dengan etika etos kerja, serta nilai dengan etika pengembangan peradaban, dengan segala dinamikanya.

\section{DAFTAR PUSTAKA}

Agustian, Ginanjar, A. (2012). ESQ Emotional Spiritual Qoutient. Penerbit Arga.

Al-Jailani, Abdul Qadir, S. (2012). Buku Pintar Tasawuf (Juman Rofarif (ed.)). Penerbit Zaman.

Anwar, R. (2019). Ilmu Tasawuf. Cv. Pustaka Setia.

Arikunto, S. (2010). Prosedur Penelitian Suatu Pendekatan Praktik. Rineka Cipta.

As-Sakandari, Athoillah, Ibnu, S. (2011). Al-Hikam (Ustadz Fatihuddin Abul Yasin (ed.)). Terbit Terang.

Burhanuddin, U., \& Anwar, C. (2014). Tafsir Ayat-ayat Pendidikan. UIN Bandung Press.

Hamka. (2015). Tasawuf Modern. Republika.

Kholidah, Nur, L., \& Nasih, Munjin, A. (2009). Metode Dan Teknik Pembelajaran Pendidikan Agama Islam. PT. Refika Aditama.

Lexy, J. M. (2017). Metodologi Penelitian Kualitatif (Edisi Revisi) (37th ed.). PT Remaja Rosdakarya.

Mulyasa, E. (2006). Kurikulum Berbasis Kompetensi. PT. Remaja Rosdakarya.

Ni'am, S. (2008). The Wisdom Of k.h. Achmad Siddiq Membumikan Tasawuf. PT. Erlangga.

Putra, N., \& Lisnawati, S. (2012). Penelitian Kualitatif Pendidikan Agama Islam. PT. Remaja Rosdakarya. 
561 Peran Terekat Sufi Serta Relevansinya Terhadap Pendidikan Islam Modern - Herdian Kertayasa, Alfyan Syach, Rini Novianti Yusuf, Asep Supriatna

DOI: https://doi.org/10.31004/edukatif.v3i2.358

Rusli, R. (2013). Tasawuf dan Tarekat : Studi Pemikiran Dan Pengalaman Sufi. PT. Raja Grafindo Persada.

Salamah, U. (2005). Sosialisme Tarekat: Menjejaki Tradisi Dan Amaliah Spiritual Spiritual Sufisme. Humaniora-Anggota IKAPI.

Saliyo, S. (2017). Mencari Makna Hidup Dengan Jalan Sufi di Era Modern. Esoterik, 2(1), 110-128. https://doi.org/10.21043/esoterik.v2i1.1910

Subagyo, P. J. (1997). Metode Penelitian : Dalam Teori Dan Praktek. Rineka Cipta.

Sugiyono. (2011). Metode Penelitian Pendidikan: Pendekatan Kuantitatif, Kualitatif dan R\&D. Alfabeta.

Sukardi. (2011). Metodologi Penelitian Pendidikan: Kompetensi dan Praktiknya. Bumi Aksara.

Sutikno, M. S. (2006). Pendidikan Sekarang dan Masa Depan. NTP Press.

Tafsir, A. (2010). Ilmu Pendidikan Dalam Perspektif Islam. PT. Remaja Rosdakarya. 